\title{
EFFECT OF ENVIRONMENTAL TEMPERATURE AND ANESTHESIA ON THE SURVIVAL OF TOURNIQUET SHOCK IN RABBITS ${ }^{1}$
}

\author{
BY LEONARD I. KATZIN, RENATO A. RICCA, AND STAFFORD L. WARREN
}

(From the Department of Radiology of the University of Rochester School of Medicine and Dentistry, Rochester, N. Y.)

(Received for publication June 5, 1944)

In another paper (1), attention has been called to the effect which environmental temperature has in determining the survival or death of the anesthetized dog subjected to crush injury. The purpose of the present experiments is to determine whether environmental temperature has a similar influence upon the outcome of the shock experiment in a different species, namely, the rabbit, when shock is produced by the tourniquet instead of by the press. Working with burn shock in rats, certain investigators (2) reported an optimal temperature for survival at $75^{\circ} \mathrm{F}$. Others (3) published findings that indicated a possible optimum near body temperatures for shock produced by intestinal trauma. We have found (1) that the difference between $16^{\circ} \mathrm{C}$. and $28^{\circ} \mathrm{C}$. in room temperature makes the difference between survival or death of the dog in crush injury. High temperatures generally are deleterious, and low temperatures beneficial. No optimum such as that reported by the abovementioned authors could be detected for the range tested.

\section{METHODS}

Peripheral circulatory failure ("shock") was produced both in anesthetized (Nembutal) and unanesthetized rabbits by means of a tourniquet allowed to remain in place around one hind limb for 5 hours. The tourniquet consisted of a single strand of $7 \mathrm{~mm}$. gum rubber tubing, whose ends were fastened together by means of a screw clamp. The position of the tourniquet was kept fixed and reproducible by anchoring the tubing over the pubis, behind the ischium, and over the head of the femur. This takes in all of the hind limb tissue that it is practical to include in a tight tourniquet. The tubing was stretched as much as possible before placing, to ensure tightness.

1 The work described in this paper was done under a contract, recommended by the Committee on Medical Research, between the Office of Scientific Research and Development and the University of Rochester School of Medicine and Dentistry. Part of the work was also assisted by grants in aid from the Rockefeller Foundation and the Fluid Research Fund of the University of Rochester.
This arrangement gave good arterial closure, as no swelling of the leg occurred while the tourniquet was in place, and rigid paralysis set in immediately. Shortly after removal of the tourniquet, the animals go into "shock." In some experiments, intravenous veterinary Nembutal $(0.5 \mathrm{ml}$. per $\mathrm{kgm}$.) was used to immobilize the animals while the tourniquet was being applied, but it was possible to dispense with the narcosis since there was no apparent pain associated with the application of the tourniquet if rapidly done.

The animals were kept in individual cages, and water was available at all times during the experimental period. In some series, rectal temperatures were taken at hourly intervals. Survival period and the percentage of fatal outcome in the various experiments were the only criteria used for evaluation of the influence of room temperature. Room temperature was controlled by thermostat and checked by periodic thermometer measurements.

\section{RESULTS}

Animals alive 24 hours after removal of the tourniquet were classified as survivors of acute shock. The longest survival period of the group which succumbed was 18 hours. Some animals succumbed in as little as 1 hour following removal of the tourniquet. The median and modal values for the death time were between 5 and 6 hours.

As is the case with crush injury of dogs, room temperature plays an important rôle in determining survival or death. Thus, at a room temperature of $16^{\circ} \mathrm{C}$., 13 rabbits of 14 survived. At a room temperature of $20^{\circ} \mathrm{C}$., none of 17 rabbits survived; at $24^{\circ} \mathrm{C}$., 5 of 19 survived; and at $28^{\circ} \mathrm{C}$., there were 15 survivors in 36 rabbits. Eleven animals were tried at $32^{\circ} \mathrm{C}$., and all but 2 succumbed. Table I shows a summary of these findings.

The effect of room temperature is most important during the period following removal of the tourniquet. Thus, 3 rabbits were started at $28^{\circ} \mathrm{C}$., and moved to a room at $16^{\circ} \mathrm{C}$. at the time the tourniquet was removed. All of these animals were alive and in good condition at the 17 hours. They were then returned to the room 
TABLE I

Relation of temperature and Nembutal anesthesia to survival of shock induced by 5-hour application of tourniquet

\begin{tabular}{|c|c|c|c|c|c|c|c|c|c|}
\hline \multirow{2}{*}{$\begin{array}{l}\text { Room } \\
\text { temp. }\end{array}$} & \multirow{2}{*}{$\begin{array}{c}\text { Total } \\
\text { number of } \\
\text { rabbits }\end{array}$} & \multirow{2}{*}{$\begin{array}{l}\text { Number } \\
\text { surviving }\end{array}$} & \multirow{2}{*}{ Survival } & \multicolumn{3}{|c|}{ Anesthetized } & \multicolumn{3}{|c|}{ Not anesthetized } \\
\hline & & & & $\underset{\text { rabbits }}{\text { Number of }}$ & $\begin{array}{l}\text { Number } \\
\text { surviving }\end{array}$ & Survival & $\underset{\text { rabbits }}{\text { Number of }}$ & $\begin{array}{l}\text { Number } \\
\text { surviving }\end{array}$ & Survival \\
\hline $\begin{array}{l}16^{\circ} \mathrm{C} . \\
20^{\circ} \mathrm{C} . \\
24^{\circ} \mathrm{C} . \\
28^{\circ} \mathrm{C} . \\
32^{\circ} \mathrm{C} .\end{array}$ & $\begin{array}{l}14 \\
17 \\
19 \\
36 \\
11\end{array}$ & $\begin{array}{r}13 \\
0 \\
5 \\
15 \\
2\end{array}$ & $\begin{array}{c}\text { per cent } \\
93 \\
0 \\
26 \\
42 \\
18\end{array}$ & $\begin{array}{r}8 \\
17 \\
9 \\
10\end{array}$ & $\begin{array}{l}7 \\
0 \\
1 \\
4\end{array}$ & $\begin{array}{c}\text { per cent } \\
88 \\
0 \\
11 \\
40\end{array}$ & $\begin{array}{r}6 \\
10 \\
26 \\
11\end{array}$ & $\begin{array}{r}6 \\
4 \\
11 \\
2\end{array}$ & $\begin{array}{c}\text { per cent } \\
100 \\
40 \\
42 \\
18\end{array}$ \\
\hline
\end{tabular}

in which the temperature was $28^{\circ} \mathrm{C}$. Two of the 3 animals died 5 hours later, the third remaining alive until its sacrifice 12 hours later.

These experiments with rabbits also suggest that anesthesia may be an important factor in the chances for survival. This suggestion comes from a comparison of the shock survival figures with and without anesthetic (Nembutal) having been used to immobilize the rabbits during the application of the tourniquet. The experiments in which the environmental temperature was varied, or in which $16^{\circ} \mathrm{C}$. room temperature was used, are not included in these figures. Without anesthesia, 17 animals of 47 (36 per cent) survived; with preliminary anesthesia, only 5 animals of 36 (14 per cent) survived. It must be pointed out that proper controls are lacking on 2 important sets of experiments. Eliminating these $\left(20^{\circ} \mathrm{C}\right.$. and $32^{\circ} \mathrm{C}$. experiments) makes the difference much less marked.

Certain features of the trauma itself may bear further description. Upon death of the animal in shock, especially when death occurs in one of the shorter time intervals, any swelling of the injured limb is difficult to detect by external palpation. Slitting the skin of the injured limb reveals a mucilaginous mass of connective tissue saturated with a yellowish viscous fluid. Sometimes this may be tinged red. There is usually a sharp demarcation of the tissues which were proximal to the tourniquet from those distal to it. The former are the normal color of the rabbit, while the latter are heavily suffused and hemorrhagic. This difference, and the amount of fluid found, increase with the length of time elapsed since the removal of the tourniquet. The swelling of the limb muscles also increases markedly with time, this characteristic being most noticeable in the survivors sacrificed some time after the tourniquet was removed ( 24 hours and longer).

The muscles themselves show hemorrhage in variable degrees. In every case, at least occasional punctate hemorrhages can be seen scattered through the muscle tissue. In many cases, the whole limb is a deep beefy red, and there seems to have been free hemorrhage from the inter-muscular blood vessels in the interior of the leg, in addition to the intramuscular hemorrhages. There is a certain accentuation of these hemorrhagic phenomena with increased survival times, but this is not constant.

The rectal temperatures showed no significant correlations. In some rabbits that succumbed in short times, there was a tendency for the temperatures to rise until death intervened. In some that lived longer periods, there was a drop in rectal temperature, sometimes preceded by a rise, so that at death the temperatures were noticeably subnormal. Whether or not these patterns of temperature behavior were constant, death seemed to occur in either case. With the lower room temperatures, there was a tendency for the body temperatures to keep to low levels, and with high temperatures, the levels were higher.

\section{DISCUSSION}

In confirmation of our work on dogs with crush injury (1), no optimum point was found for environmental temperature influence on the survival of tourniquet shock in rabbits. The transition from high survival rates to high mortality rates occurred between $16^{\circ} \mathrm{C}$. and 
$24^{\circ} \mathrm{C}$., possibly a sharper transition than with the dogs, but in the same range. This disagrees with the reports of one group (2) for burn shock in rats, and of another (3) for intestinal trauma in rabbits and other small animals. The discrepancy between our results and those of these other workers may be due chiefly to the difference in the type and severity of the injury, with the attendant complications. The disagreement with second group' may be based on several factors, including the comparison of survival times in a uniformly lethal treatment, such as intestinal trauma, with survival rates in a different type of injury, and the difference in type and reliability of environmental temperature control used. It should be further pointed out that the temperature optima given by the two groups of investigators are distinct and different.

The possibly deleterious effect of the anesthetic suggested by the rabbit data given in this present report is in agreement with the frequent clinical reports of harmful effects of anesthetics, principally barbiturates, in cases of shock. A recent paper (5), however, claims beneficial effects of Nembutal in burns.

\section{SUMMARY}

(1) The temperature of the environment greatly affects survival rates of rabbits on whom tourniquets have been applied for 5 hours. At $16^{\circ} \mathrm{C}$. and below, survival rates are high; at $24^{\circ} \mathrm{C}$. and above, survival rates are low. This is in agreement with the findings in crush injury by means of the press in dogs.

(2) Nembutal anesthesia may possibly affect the survival rate since 26 per cent (5 out of 19 rabbits) survived when Nembutal was used, and 41 per cent (15 out of 36 rabbits) survived when no anesthesia was employed in controlled experiments. The room temperature was in the lethal range of $24^{\circ} \mathrm{C}$. to $28^{\circ} \mathrm{C}$.

\section{BIBLIOGRAPHY}

1. Ricca, R. A., Fink, K., Katzin, L. I., and Warren, S. L., Effect of environmental temperature on experimental traumatic shock in dogs. J. Clin. Invest., 1945, 24, 127.

2. Elman, R., Cox, W. M. Jr., Lischer, C. E., and Mueller, A. J., Mortality in severe experimental burns as affected by environmental temperature. Proc. Soc. Exper. Biol. and Med., 1942, 51, 350.

3. Wakim, K. G., and Gatch, W. D., The effect of external temperature on shock. J.A.M.A., 1943, $121,903$.

4. Allen, F. M., Physical and toxic factors in shock. Arch. Surg., 1939, 38, 155.

5. Beecher, H. K., and McCarrell, J. D., Reduction of fluid loss from damaged (burned) tissues by a barbiturate. J. Pharmacol. and Exper. Therap., 1943, 78, 39.

6. Govier, W. M., Studies on shock induced by hemorrhage. J. Pharmocol. and Exper. Therap., 1943, 77, 40. 